\title{
LICHENS AND LICHENICOLOUS FUNGI OF THE AZORES (PORTUGAL), COLLECTED ON SÃO MIGUEL AND TERCEIRA WITH THE DESCRIPTIONS OF SEVEN NEW SPECIES
}

\author{
P. P. G. vAN DEN BoOM \\ Arafura 16, 5691 JA, Son, the Netherlands; E-mail: pvdboom@kpnmail.nl
}

(Received 23 September, 2015; Accepted 5 January, 2016)

\begin{abstract}
One hundred lichen species and lichenicolous fungi are reported from the Azores, occurring on São Miguel and/or Terceira, collected in 2011 and 2014. Thirty-seven species are newly recorded to the Azores and seven are described as new to science: Byssoloma fuscum, Lecania azorica, Sphaerellothecium heterodermiae, S. parmotremae, Stigmidium micareae, S. subcladoniicola, Thelocarpon microsporum.
\end{abstract}

Key words: biodiversity in lichens and lichenicolous fungi, ecology, Macaronesia, new records, taxonomy

\section{INTRODUCTION}

The Azores are a group of volcanic islands in the Atlantic Ocean, nearly $1,400 \mathrm{~km}$ west of the mainland of Portugal. There are 9 major islands, which have volcanic origins. Mount Pico, on the island of Pico, is the highest point in the archipelago, at 2,351 m. The islands visited for the study below, are characterised by a hilly landscape with the highest point on São Miguel, ca $1,100 \mathrm{~m}$ and the highest point on Terceira, $c a 1,000 \mathrm{~m}$. There is an existing checklist of lichens and lichenicolous fungi, which has been published online by Gabriel (2008), in which distribution of the species can be found from all over these nine islands. During October 2011 and June-July 2014 the author and his wife gathered ca 1,000 specimens on two islands, São Miguel and Terceira, respectively. These collections included almost all previously reported species, as well as numerous new records to the Azores or new to one or two studied islands. Seven species are described as new to science and several others are to be studied in the future. One hundred lichen species and lichenicolous fungi are reported from the Azores, of which thirty seven species are newly recorded to the archipelago and seven are described as new to science. 


\section{MATERIALS AND METHODS}

All collected specimens have been studied by conventional macro- and microscopical techniques with hand-cut sections of the material mounted in tap water. Amyloid reactions were tested using Lugol's iodine solution (K/I). Some specimens were identified by specialists (see acknowledgements). All localities are provided with geographical coordinates based on GPS and mentioned below. Photographs of habitus are provided for the seven new species. Voucher specimens are kept in the herbarium of P. P. G. van den Boom, some specimens, especially type specimens are deposited in the herbarium of Berlin (B). Distribution data were taken from the checklists of the Azores (Gabriel 2008).

\section{Localities São Miguel}

$1=\mathrm{N}$ of Ponta Delgada, Capelas, trees (cf. Acacia) and wall of volcanic stones in village, $37^{\circ}$ $49.80^{\prime} \mathrm{N} ; 25^{\circ} 40.50^{\prime} \mathrm{W}, 55 \mathrm{~m}, 24$ October 2011.

2 = Ponta Delgada, centre of city, botanical garden 'Jardim Joséo Canto', origin from 1840,

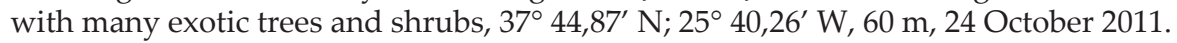

$3=\mathrm{NW}$ of Ponta Delgada, road to Sete Cidades, SE of village, near view points between

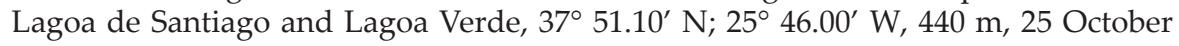
2011.

4 = NW of Ponta Delgada, Sete Cidades, centre of village, two rows of mature Cryptomeria japonica trees in front of the church and small park with mixed small trees, $37^{\circ} 51.80^{\prime}$ N; $25^{\circ} 47.90^{\prime} \mathrm{W}, 270 \mathrm{~m}, 25$ October 2011.

5 = NW of Ponta Delgada, E of Sete Cidades, peninsula 'Tufo' in Lagoa Azul, mixed trees

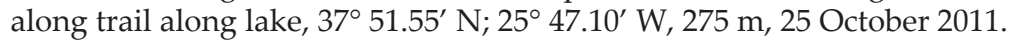

$6=\mathrm{Ca} 4 \mathrm{~km}$ SE of Ribeira Grande, S of Caldeiras, trail to Mata do Botelho, forest with strong sloping sand and outcrops, an area very poor in lichens, $37^{\circ} 47.50^{\prime} \mathrm{N} ; 25^{\circ} 29.10^{\prime} \mathrm{W}$, $335 \mathrm{~m}, 26$ October 2011.

$7=\mathrm{E}$ of Ribeira Grande, $\mathrm{S}$ of Porto Formosa, along road EN1, near tea factory, garden with mixed trees, $37^{\circ} 48.93^{\prime} \mathrm{N} ; 2^{\circ} 25.55^{\prime} \mathrm{W}, 140 \mathrm{~m}, 26$ October 2011.

$8=$ ENE of Vila Franca, Furnas centre, botanical garden 'Terra Nostra', origin from 1780, with mixed exotic and endemic trees and shrubs, $37^{\circ} 46.40^{\prime} \mathrm{N} ; 2^{\circ} 18.80^{\prime} \mathrm{W}, 205 \mathrm{~m}$, 27 October 2011.

$9=$ WNW of Ponta Delgada, NW of Relva, along trail from Vigia to Rocha da Relva, steep cliffs in coastal area, $37^{\circ} 46.50^{\prime} \mathrm{N} ; 2^{\circ} 45.30^{\prime} \mathrm{W}, 35 \mathrm{~m}, 28$ October 2011.

$10=$ NW of Ponta Delgada, NW of Ginetes, Ponta da Ferraria, view point with low sloping outcrops and Erica azorica shrubs and steep outcrops near road, in W exposed coastal area, $37^{\circ} 51.50^{\prime} \mathrm{N} ; 5^{\circ} 51.10^{\prime} \mathrm{W}, 110 \mathrm{~m}, 28$ October 2011.

$11=$ NW of Ponta Delgada, along road EN1 between Ginetes and Mosteiros, SE of Lomba da Fonte, on picnic place, mixed trees, $37^{\circ} 52.55^{\prime} \mathrm{N} ; 25^{\circ} 49.50^{\prime} \mathrm{W}, 185 \mathrm{~m}, 28$ October 2011.

$12=$ NE of Furnas, trail from main road near Pico do Salto do Cavalo to Sebastião Alves, open grassy area (rather wet soil) with some small groups of Cryptomeria trees and one solitary Acer tree, 37 47.50’ N; 25 16.50’ W, 875 m, 29 October 2011. 
$13=\mathrm{N}$ of Nordeste, trail NE of Lomba Fazenda, Parque de Endémicas, coastal area with mainly Erica azorica shrubs and shaded and sheltered volcanic outcrops in small valley, $37^{\circ} 51.00^{\prime} \mathrm{N} ; 25^{\circ} 09.10^{\prime} \mathrm{W}, 30 \mathrm{~m}, 29$ October 2011.

14 = Lagoa de Fogo, Caldeira Velha, forest with mixed trees and many tree ferns, near swimming pool, $37^{\circ} 46.85^{\prime} \mathrm{N} ; 2^{\circ} 29.80^{\prime} \mathrm{W}, 465 \mathrm{~m}, 30$ October 2011.

15 = Lagoa de Fogo, west side of lake, $\mathrm{N}$ of mountain top 'Barrosa', grassy slopes along road, on soil, $37^{\circ} 45.70^{\prime} \mathrm{N} ; 2^{\circ} 29.60^{\prime} \mathrm{W}, 875 \mathrm{~m}$, 30 October 2011.

$16=$ NW of Lagoa de Fogo, along road, between Caldeira Velha and lake, near entrance of factory or energy, steep sandy slopes and short path with grassy soil, $37^{\circ} 46.70^{\prime} \mathrm{N} ; 25^{\circ}$ $29.55^{\prime} \mathrm{W}, 530 \mathrm{~m}, 30$ October 2011.

17 = Villa Franca, N side of village, near Senhora da Paz, chapel, on S exposed slope, garden with Cryptomeria trees and Azalea shrubs, dead tree in field, $37^{\circ} 43.68^{\prime} \mathrm{N} ; 25^{\circ} 25.90^{\prime}$ W, $225 \mathrm{~m}, 30$ October 2011.

\section{Localities Terceira}

$18=$ NW of Angra do Heroismo, Reserva Florestal Viveira da Falca, picnic area, with many mature Cryptomeria trees, some Acer trees and on Camellia, $38^{\circ} 42.90^{\prime} \mathrm{N} ; 27^{\circ} 16.78^{\prime} \mathrm{W}$, $460 \mathrm{~m}$, 28 June 2014.

19 = NW of Angra do Heroismo, W of Pico Gordo, Mistério dos Negros (N), trial from Lagoa do Negro to Juniperus forest, fence posts along fields, some rows of Cryptomeria trees and heathland with young Cryptomeria, $38^{\circ} 44.27^{\prime} \mathrm{N} ; 27^{\circ} 16.60^{\prime} \mathrm{W}, 570 \mathrm{~m}, 28$ June 2014.

20 = NW of Angra do Heroismo, W of Pico Gordo, Mistério dos Negros (N), trial from Lagoa do Negro to the west, \pm damp Juniperus brevifolia forest, with some young Vaccinium cylindraceum, 38 44.15' N; 27 16.30’ W, 555 m, 28 June 2014.

21 = NW of Angra do Heroismo, south edge of Reserva Florestal da Lagoa das Patas, area around a pond 'Lagoa das Patas', mature Cryptomeria trees and some Camellia shrubs, $38^{\circ} 43.01^{\prime} \mathrm{N} ; 27^{\circ} 17.32^{\prime} \mathrm{W}, 520 \mathrm{~m}, 28$ June 2014.

$22=\mathrm{W}$ of Praia da Vitória, $\mathrm{S}$ of São Brás, $\mathrm{S}$ of Baldio, picnic area, starting point for trail to Biscoito da Fontinhas, mixed trees, including Myrica faya, $38^{\circ} 44.90^{\prime} \mathrm{N} ; 27^{\circ} 07.83^{\prime} \mathrm{W}$, $195 \mathrm{~m}, 29$ June 2014.

23 = W of Praia da Vitória, S of São Brás, Serra do Cume, wall of volcanic stones and grassy slope, 38 42.57' N; $27^{\circ} 06.74^{\prime} \mathrm{W}, 530 \mathrm{~m}, 29$ June 2014.

$24=\mathrm{W}$ of Praia da Vitória, S of São Brás, E side of highway, N of road ER2, Cabouco, small open forest with mainly Eucalyptus trees, 38 $43.03^{\prime} \mathrm{N} ; 27^{\circ} 09.09^{\prime} \mathrm{W}, 350 \mathrm{~m}$, 29 June 2014.

25 = Angra do Heroismo, centre, garden with many stairs $(>100)$, with mixed trees, $38^{\circ}$ 39.43' N; $27^{\circ} 13.05^{\prime} \mathrm{W}, 35 \mathrm{~m}$, 30 June 2014.

26 = Angra do Heroismo, Monte Brasil, recreation-ground, small (low) shrubs of Camellia, Tamarix and old wall of fortress, 38 39.00' N; $27^{\circ} 13.47^{\prime} \mathrm{W}, 60 \mathrm{~m}$, 30 June 2014.

27 = Angra do Heroismo, Monte Brasil, NW slope, road from fortress to Pico das Cruzinhas, roadside trees along forest, $38^{\circ} 38.87^{\prime} \mathrm{N} ; 27^{\circ} 13.71^{\prime} \mathrm{W}, 70 \mathrm{~m}$, 30 June 2014.

28 = Angra do Heroismo, Monte Brasil, top, area of Pico das Cruzinhas, including picnic area, mixed trees and shrubs, included Myrica faya and Erica, $38^{\circ} 38.78^{\prime}$ N; $27^{\circ} 13.73^{\prime}$ W, 100 m, 30 June 2014. 
$29=\mathrm{W}$ of Angra do Heroismo, W of São Mateus, Forte do Negrito, coastal volcanical outcrops, 38 39.34' N; $27^{\circ} 17.06^{\prime} \mathrm{W}, 5 \mathrm{~m}, 1$ July 2014.

$30=\mathrm{W}$ of Angra do Heroismo, $\mathrm{W}$ of São Mateus, Cinco Ribeiras, centre, in front of church, Morus trees, 38 $41.09^{\prime}$ N; $27^{\circ} 19.08^{\prime}$ W, 130 m, 1 July 2014.

$31=\mathrm{W}$ of Angra do Heroismo, W of São Mateus, SW of Cinco Ribeiras, coastal area, near Porto das Cinco Ribeiras, campsite, Tamarix trees, $38^{\circ} 40.57^{\prime}$ N; $27^{\circ} 19.76^{\prime}$ W, 15 m, 1 July 2014.

$32=\mathrm{W}$ of Angra do Heroismo, SW of Santa Bárbara, coastal area, picnic area, overhanging shaded and sheltered outcrops in small valley, $38^{\circ} 41.47^{\prime} \mathrm{N} ; 27^{\circ} 21.26^{\prime} \mathrm{W}, 30 \mathrm{~m}, 1 \mathrm{July}$ 2014.

33 = NW of Angra do Heroismo, NNE of Santa Bárbara, Serra de Santa Bárbara, just below the summit, low vegetation with outcrops in small stream, $38^{\circ} 43.66^{\prime} \mathrm{N} ; 27^{\circ} 19.40^{\prime} \mathrm{W}$, 970 m, 1 July 2014.

$34=$ NW of Angra do Heroismo, NNE of Santa Bárbara, Serra de Santa Bárbara, road to the summit, forests with mainly Cryptomeria trees, trees at edge of forest, $38^{\circ} 43.49^{\prime} \mathrm{N} ; 27^{\circ}$ 19.33’ W, 800 m, 1 July 2014.

$35=$ WNW of Angra do Heroismo, NNE of Santa Bárbara, Cerrado das Sete, picnic area with mature Cryptomeria trees, 38 42.60’ N; 27 19.52’ W, 460 m, 1 July 2014.

$36=$ NNE of Angra do Heroismo, $\mathrm{W}$ of Cabrita, roadside (road ER5) Cryptomeria trees, $38^{\circ}$ 43.02' N; $27^{\circ} 11.09^{\prime} \mathrm{W}, 440$ m, 1 July 2014.

37 = NE of Serreta, parking lot for trail to Lagoínha, mature Myrica faya tree (solitary) along

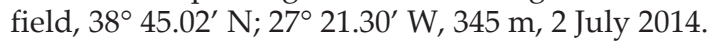

$38=$ NE of Serreta, north trail to Lagoínha, Cryptomeria japonica trees (in forest), Myrica faya trees, Erica, etc., 38 $45.28^{\prime}$ N; $27^{\circ} 20.50^{\prime}$ W, 500 m, 2 July 2014.

$39=$ NE of Serreta, north trail to Lagoínha, rather wide open trail with unidentified small trees (cf. Ilex perado subsp. azorica) at the edge of forest, $38^{\circ} 45.15^{\prime} \mathrm{N} ; 27^{\circ} 20.17^{\prime} \mathrm{W}, 600 \mathrm{~m}$, 2 July 2014.

$40=\mathrm{N}$ of Serreta, Reserva Florestal da Serreta, picnic area in open forest with mixed trees and shrubs, $38^{\circ} 46.27^{\prime} \mathrm{N} ; 27^{\circ} 21.42^{\prime} \mathrm{W}, 80 \mathrm{~m}$, 2 July 2014.

$41=$ WNW of Vila Nova, SE of Furnas das Pombas, coastal area, small road with $\mathrm{W}$ exposed volcanic outcrops, 38 $47.68^{\prime} \mathrm{N} ; 2^{\circ} 11.70^{\prime} \mathrm{W}, 50 \mathrm{~m}$, 3 July 2014.

$42=$ WNW of Vila Nova, SW of Furnas das Pombas, coastal area, Farroco, small trail to the coast from road EN1, rather shaded area with mixed trees and shrubs, $38^{\circ} 47.71^{\prime} \mathrm{N}$; $27^{\circ} 11.99^{\prime}$ W, 25 m, 3 July 2014.

$43=\mathrm{W}$ of Vila Nova, Farroco, small road (trail) to the south, Biscoito das Calmeinas (W), free standing mature Myrica faya tree along field, $38^{\circ} 46.96^{\prime} \mathrm{N} ; 27^{\circ} 12.51^{\prime} \mathrm{W}, 85 \mathrm{~m}, 3$ July 2014.

$44=\mathrm{S}$ of Biscoitos, along road to the south (to Macieira), picnic area with mixed trees and

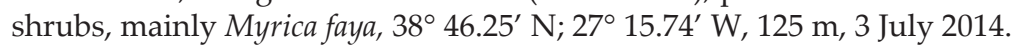

$45=\mathrm{N}$ of Angra do Heroismo, ENE of Bagacina, Furnas do Enxofre, short trail along hot springs, on wood of fence and among shrubs and a small laurisilva with Vaccinium cylindraceum, 38 43.79’ N; 27 13.95’ W, 575 m, 3 July 2014.

$46=\mathrm{N}$ of Angra do Heroismo, E of Bagacina, Algar do Carvão, hilly area near cave, with

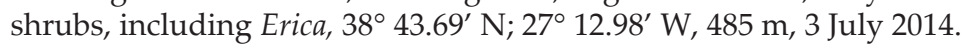

$47=$ NNE of Angra do Heroismo, Cabrito, NW of Pico da Cruz, N side of road ER5, some Cryptomeria trees at winding of the road to the north, $38^{\circ} 43.20^{\prime} \mathrm{N} ; 27^{\circ} 11.00^{\prime} \mathrm{W}, 225 \mathrm{~m}$, 3 July 2014. 


\section{RESULTS}

\section{Byssoloma fuscum van den Boom, spec. nova}

(Fig. 1)

Mycobank no.: MB 815833

Species similar to Byssoloma marginatum (Arnold) Sérus., but differs by very thin, greenish grey thallus, and smaller apothecia, up to $0.25 \mathrm{~mm}$, soon becoming strongly convex, ascospores (17-)20-25 × (4-)4.5-5.5 $\mu \mathrm{m}$, (3-)5-septate.

Type: Portugal; Azores, Terceira, N of Angra do Heroismo, E of Bagacina, Algar do Carvão, hilly area near cave, with shrubs, including Erica, $38^{\circ} 43.69^{\prime} \mathrm{N} ; 27^{\circ} 12.98^{\prime} \mathrm{W}$, on Erica, 485 m, 03.07.2014, P. \& B. van den Boom 51850 (holotype: B; isotype: hb. v. d. Boom).

Thallus corticolous, continuous, greenish grey, very thin, up to $0.1 \mathrm{~mm}$ thick, often almost indistinct; prothallus absent; upper surface smooth to slightly shiny, pale to moderately greyish brown; photobiont chlorococcoid, cells of 5 to $12 \mu \mathrm{m}$ in diam.

Apothecia scattered, up to $0.25 \mathrm{~mm}$ in diam., disc at first slightly convex but becoming strongly convex soon, dark brown, margin very thin, slightly paler brown than the disc, but soon disappearing; excipulum lecideine, not cellular, inner part pale brownish, base of the apothecia sometimes with a pale rim of outwardly directed hyphae; epihymenium, dark reddish brown, paler in $\mathrm{KOH}$; hymenium ca 55-70 $\mu \mathrm{m}$ high, hyaline; hypothecium dark brown; paraphyses strongly conglutinated, cells in the middle of the hymenium 1.5-2 $\mu \mathrm{m}$ in diam., simple to sometimes branched in the upper part, apices brown pigmented, widened up to $3 \mu \mathrm{m}$; asci Byssoloma-type, 8-spored, 25-37 × 15-20 $\mu \mathrm{m}$; ascospores (17-)20-25 × (4-)4.5-5.5 $\mu \mathrm{m}$, (3-)5-septate, ellipsoid, always well developed and abundantly present. Pycnidia not found.

Chemistry: Thallus K-, C-, KC-, P-; no chemical compounds detected.

Etymology: The epithet refers to the colour of the apothecia.
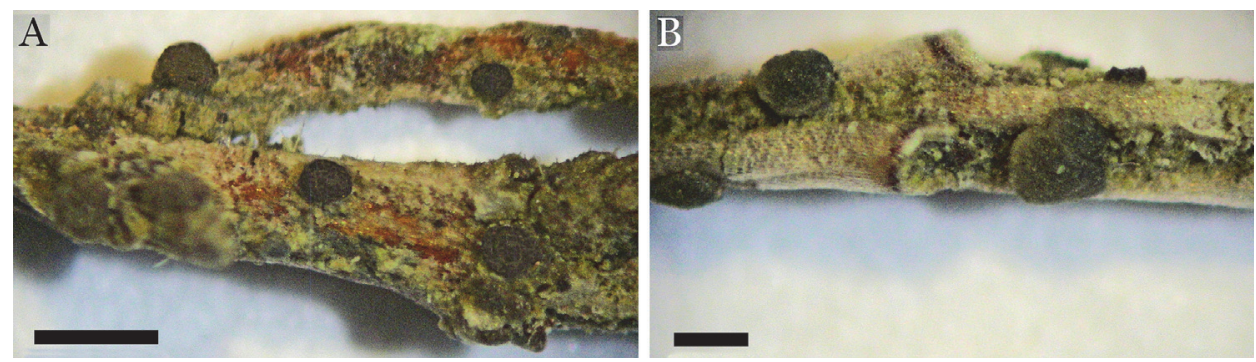

Fig. 1. Byssoloma fuscum (holotype): $\mathrm{A}=$ habitus with mature apothecia; $\mathrm{B}=$ habitus with young apothecia. Scale $A=0.5 \mathrm{~mm}, B=0.2 \mathrm{~mm}$ 
Distribution and ecology: This new species occurs on three localities rather widely distributed in Terceira, from the centre to the west. It is known from trunks of Cryptomeria japonica and Erica, but on this latter phorophyte only on twigs, where it is very inconspicuous. It occurs in inland in hilly areas. Most probably the species is not rare, because it is very easily overlooked. In the field it looks as a small not well developed Byssoloma marginatum. It has been found growing close to this latter species.

Taxonomic notes: Byssoloma fuscum is the most similar with B. marginatum (Arnold) Sérus., but it is much smaller in habitus having thinner thallus and smaller apothecia, it appears as B. marginatum. This latter has wider apothecia (up to $0.7 \mathrm{~mm}$ in diam.) with a rather conspicuous, persistent pale margin and smaller ascospores, 12-18 × 3-5 $\mu \mathrm{m}$, always 3-septate. Fellhaneropsis myrtillicola (Erichsen) Sérus. et Coppins, is easily overlooked for the new species, because it has also small dark apothecia of $0.1-0.2(-0.3) \mathrm{mm}$, which are even convex and immarginate when mature, but these apothecia have mostly a bluish tinge. The ascospores are different, oblong-fusiform 16-28(-34) $\times 3-4$ $\mu \mathrm{m}, 3(-5)$-septate.

Additional specimens examined: Portugal; The Azores, Terceira, WNW of Angra do Heroismo, NNE of Santa Bárbara, Cerrado das Sete, picnic area with mature Cryptomeria trees, $38^{\circ} 42.60^{\prime} \mathrm{N} ; 27^{\circ} 19.52^{\prime}$ W, 460 m, 01.07.2014, P. \& B. van den Boom 51647, 51655 (hb. v. d. Boom); NE of Serreta, north trail to Lagoínha, Cryptomeria japonica trees (in forest), Myrica faya trees and Erica, 38 45.28' N; $27^{\circ} 20.50^{\prime}$ W, 500 m, 02.07.2014, P. \& B. van den Boom 51877 (hb. v. d. Boom).

Lecania azorica van den Boom, spec. nova (Fig. 2)

MycoBank no.: MB 815834

Species similar to Lecania nigra van den Boom et Ertz, but differs by areolate thallus having wider areoles, up to $0.5 \mathrm{~mm}$, bigger, erumpent apothecia, up to 0.4 $\mathrm{mm}$, with thalline margin when young, later becoming excluded, disc reddish brown, with a more prominent margin with a small black rim, then nearly lecideine, ascospores 10-12 × 4.5-5.5 $\mu \mathrm{m}$, ellipsoid, 1-septate. Pycnidia not found.

Type: Portugal; The Azores, São Miguel, concrete of wall, $37^{\circ} 46.5^{\prime}$ N; $25^{\circ} 45.3^{\prime}$ W, 35 m, 28.10.2011, P. \& B. van den Boom 46680 (holotype: B; isotype: hb. v. d. Boom).

Thallus saxicolous, areolate to sometimes rimose, up to $0.2 \mathrm{~mm}$ thick; areoles up to $0.5 \mathrm{~mm}$ wide, upper surface smooth to slightly uneven, the are- 
oles often slightly upturning at the edge, upper surface pale to moderately greyish brown; photobiont chlorococcoid, cells of 5 to $14 \mu \mathrm{m}$ in diam.

Apothecia erumpent, up to $0.4 \mathrm{~mm}$ in diam., when young with a thick thalline margin, evanescent when mature; disc plane to slightly convex, reddish brown, margin becoming darker than the disc, blackish when mature, persistent; excipulum in mature apothecia lecideine, not cellular, black at the rim, inner part hyaline, chlorococcoid algae developed mainly below the hypothecium; epihymenium, dark reddish brown, paler in $\mathrm{KOH}$; hymenium ca 60-70 $\mu \mathrm{m}$ high, hyaline; hypothecium hyaline; paraphyses conglutinated, septate, cells in the middle of the hymenium 1.5-2 $\mu \mathrm{m}$ in diam., simple to sometimes branched in the upper part, apices brown pigmented, widened up to $5 \mu \mathrm{m}$; asci Bacidia-type, 8-spored, 40-50 × 10-15 $\mu \mathrm{m}$; ascospores 10-12 $\times$ 4.5-5.5 $\mu \mathrm{m}$, ellipsoid 1-septate. Pycnidia not found.

Chemistry: Thallus K-, C-, KC-, P-; no chemical compounds detected.

Etymology: The epithet refers to the archipelago where it has been found.

Distribution and ecology: This new species occurs on concrete of a wall in a coastal area (Atlantic coast), along a steep cliff, $c a 35 \mathrm{~m}$ altitude. It is currently known only from the type locality.

Taxonomic notes: Lecania azorica is easily characterised by the erumpent young apothecia with a pale thalline and by the dark rim on the mature apothecia, it is somewhat similar with Lecania rabenhorstii (Hepp) Arnold, but that species has mainly crowded apothecia, which are slightly to strongly convex and they are not erumpent and the dark rim is lacking, the ascospores are usually somewhat wider.
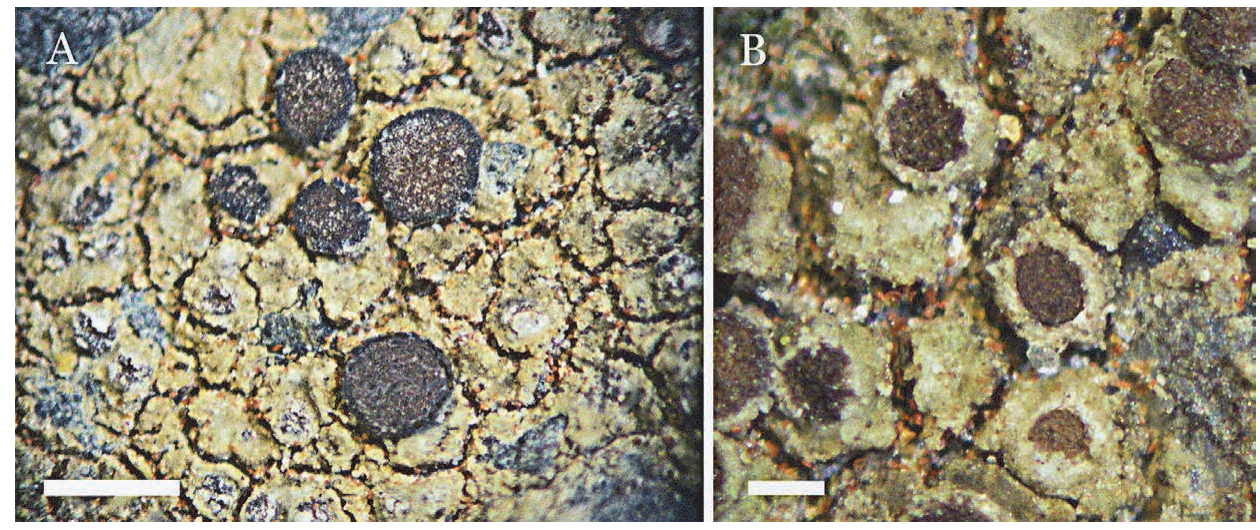

Fig. 2. Lecania azorica (holotype): $\mathrm{A}=$ habitus with mature apothecia; $\mathrm{B}=$ habitus with young apothecia. Scale $\mathrm{A}=0.5 \mathrm{~mm}, \mathrm{~B}=0.2 \mathrm{~mm}$ 
Sphaerellothecium heterodermiae van den Boom, spec. nova (Fig. 3)

Mycobank no.: MB 815835

Sphaerellothecium in thallus of Heterodermia albicans (Pers.) Swinscow $\mathcal{E}$ Krog. Vegetative hyphae immersed, 3-4.5 $\mu \mathrm{m}$ thick; ascomata perithecioid, globose, semi-immersed, dark brown to blackish, 30-60(-70) $\mu \mathrm{m}$ in diam., perithecial wall dark brown $\mathrm{K}-$, cells in surface view roundish to angular, or slightly elongate, 5-8 $\times$ 3-6 $\mu \mathrm{m}$; asci 22-28 × 11-17 $\mu \mathrm{m}, 8$-spored; ascospores with 1-2 guttules per cell, $6-10 \times(2.7-) 3-4 \mu \mathrm{m}$.

Type: Spain; Canary Islands, Tenerife, Las Montanas de Anaga, ENE of Chamorga, first part of Barranco de Roque Bermej, SW exposed strong sloping outcrops along trail to the most northeastern part of the island, $28^{\circ} 34.29^{\prime} \mathrm{N} ; 016^{\circ} 09.27^{\prime} \mathrm{W}, 400 \mathrm{~m}, 01.03 .2011$, P. \& B. van den Boom 45691 (holotype: B; isotype: hb. v. d. Boom).

Vegetative hyphae immersed, 3-4.5 $\mu \mathrm{m}$ thick; cell wall dark brown, smooth, sometimes branched.

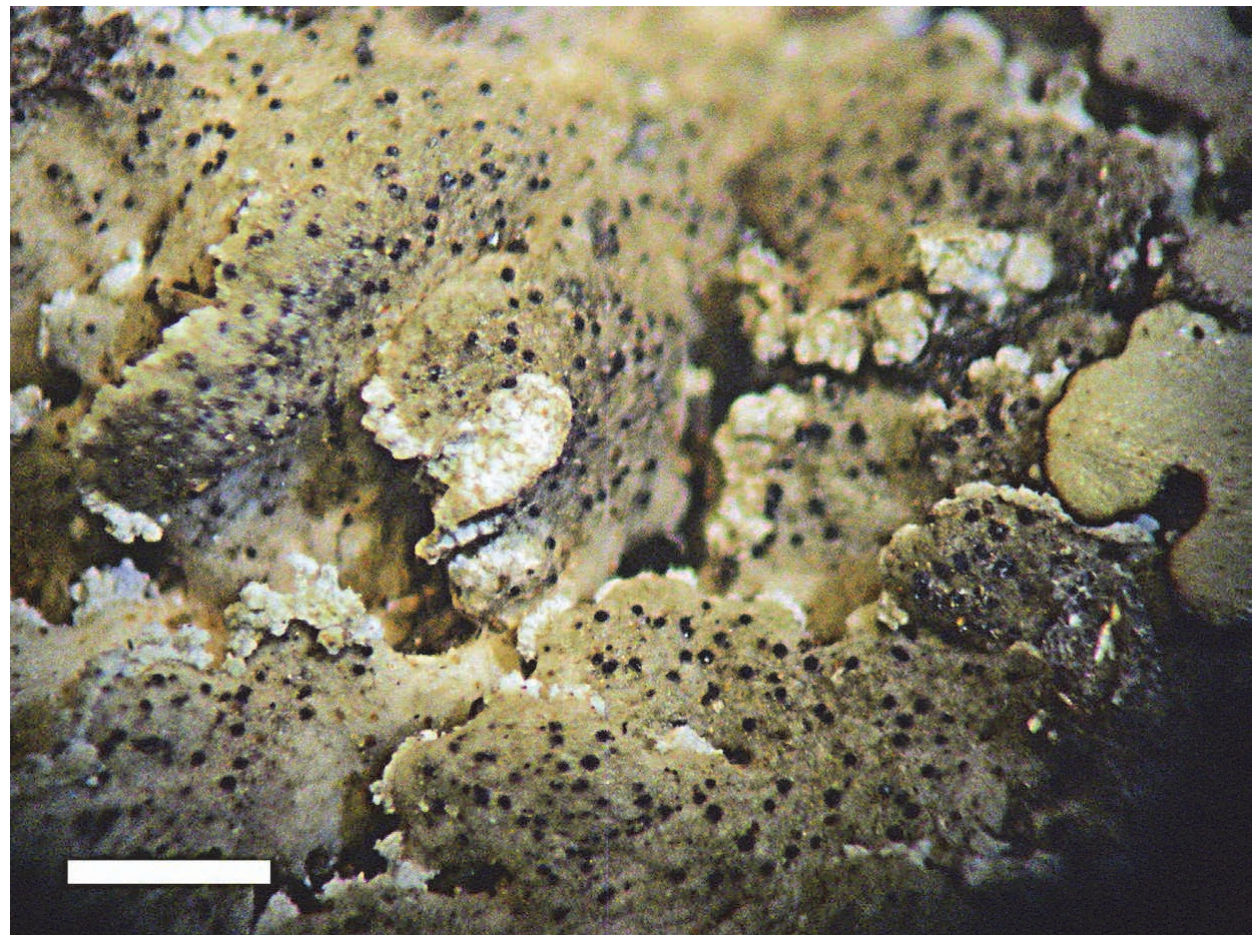

Fig. 3. Sphaerellothecium heterodermiae (holotype): habitus with immersed perithecia. Scale $=0.5 \mathrm{~mm}$ 
Ascomata perithecioid, globose, semi-immersed, breaking through the cortex of the host, dark brown to blackish, 30-60(-70) $\mu \mathrm{m}$ in diam., abundantly present on each infected thallus lobe; perithecial wall dark brown, $\mathrm{K}$-, cells in surface view roundish to angular, or slightly elongate, 5-10 × 3-6 $\mu \mathrm{m}$; wall irregularly thickened; periphyses not observed; centrum K/I-, without any visible paraphysoids or pseudoparaphyses; asci shortly and widely ellipsoid to obpyriform, wall apically thickened, with a distinct ocular chamber, K/I- (but epiplasma K/I+ orange to red), 22-28 × 11-17 $\mu \mathrm{m}, 8$-spored; ascospores hyaline, broadly ellipsoid to ovoid, 1-septate, smooth walled, often with a small perispore, with 1 guttule per cell, $6-10 \times(2.7-) 3-4 \mu \mathrm{m}$, upper cell slightly broader and often shorter. Pycnidia not observed.

Etymology: The epithet refers to the host genus.

Distribution and ecology: The species is known from the Canary Islands (Tenerife and La Palma) and the Azores (São Miguel), from coastal to inland areas. The host is always Heterodermia albicans (Pers.) Swinscow et Krog. Growing on volcanic rocks.

Taxonomic notes: In Diederich (2007), there are notes mentioned on this species. It is proposed that it most probably regards a new species, but better material is needed to describe it. However, the type material is a very well developed specimen, in which perithecia are abundantly present. Sphaerellothecium gallowayi Diederich is the most related to the new species, because of the somewhat comparable measurements of perithecia $(30-60(-70) \mu \mathrm{m}$ in the new species, $30-45(-60) \mu \mathrm{m}$ in $S$. gallowayi, asci $(22-28 \times 11-17 \mu \mathrm{m}$ in the new species, $17-27 \times 9-13 \mu \mathrm{m}$ in $S$. gallowayi), and ascospores $(6-10 \times(2.7-) 3-4$ $\mu \mathrm{m}$ in the new species, and 7.5-10 $\times(2.5-) 3-4 \mu \mathrm{m}$ in S. gallowayi). However, this latter species has clearly visible vegetative hyphae on the host cortex. In S. gallowayi the ascomata are not breaking through the cortex of the host, as it is in the new species and they are much more scattered, so there are much less number of ascomata on each infected thallus lobe, the average distance between ascomata in the new species is ca $70 \mu \mathrm{m}$, in S. gallowayi it is $>200 \mu \mathrm{m}$. It occurs on different host species of the genus Heterodermia.

Additional specimens examined: Spain; Canary Islands, La Palma, $3.5 \mathrm{~km}$ NNE of Santa Cruz, Tenagua, $0.3 \mathrm{~km}$ NE of crossing with main road, road to P. S. Lucia, NW exp. rocky slope with Kleinio-Euphorbietum, $28^{\circ} 42.80^{\prime}$ N; 17 44.70’ W, 280 m, 05.05.1999, P. \& B. van den Boom 22485 (hb. v. d. Boom). - Portugal; The Azores, São Miguel, WNW of Ponta Delgada, NW of Relva, along trail from Vigia to Rocha da Relva, steep cliffs in coastal area, $37^{\circ} 46.50^{\prime} \mathrm{N} ; 25^{\circ} 45.30^{\prime}$ W, 35 m, 28.10.2011, P. \& B. van den Boom 46677 (hb. v. d. Boom). 
Sphaerellothecium parmotremae van den Boom, spec. nova (Fig. 4)

Mycobank no.: MB 815836

Sphaerellothecium in thallus of Parmotrema perlatum (Huds.) M. Choisy. Vegetative hyphae semi-immersed, 3.0-4.5(-5) $\mu \mathrm{m}$ thick; ascomata perithecioid, globose, immersed to semi-immersed, dark brown to blackish, 30-50 $\mathrm{mm}$ in diam., perithecial wall dark brown $\mathrm{K}-$, cells in surface view of angular to somewhat elongate, 3-5 $\times 3-8 \mu \mathrm{m}$ wide; asci 22-27 × 10-12 $\mu \mathrm{m}, 8$-spored; ascospores mostly with 2 guttules per cell, $8-10 \times(2.5-) 3-3.5 \mu \mathrm{m}$.

Type: Portugal; The Azores, São Miguel, N of Nordeste, trail NE of Lomba Fazenda, Parque de Endémicas, coastal area with mainly Erica azorica shrubs and shaded and sheltered volcanic outcrops in small valley, $37^{\circ} 51.00^{\prime} \mathrm{N} ; 25^{\circ} 9.10^{\prime} \mathrm{W}, 30 \mathrm{~m}, 29.10 .2011$, P. \& B. van den Boom 46785 (holotype: B; isotype: hb. v. d. Boom).

Vegetative hyphae semi-immersed, visible macroscopically, in pinkish discoloration of the thallus, with a bluish rim, 3.0-4.5(-5) $\mu \mathrm{m}$ thick, elongate; cell wall dark brown, smooth.

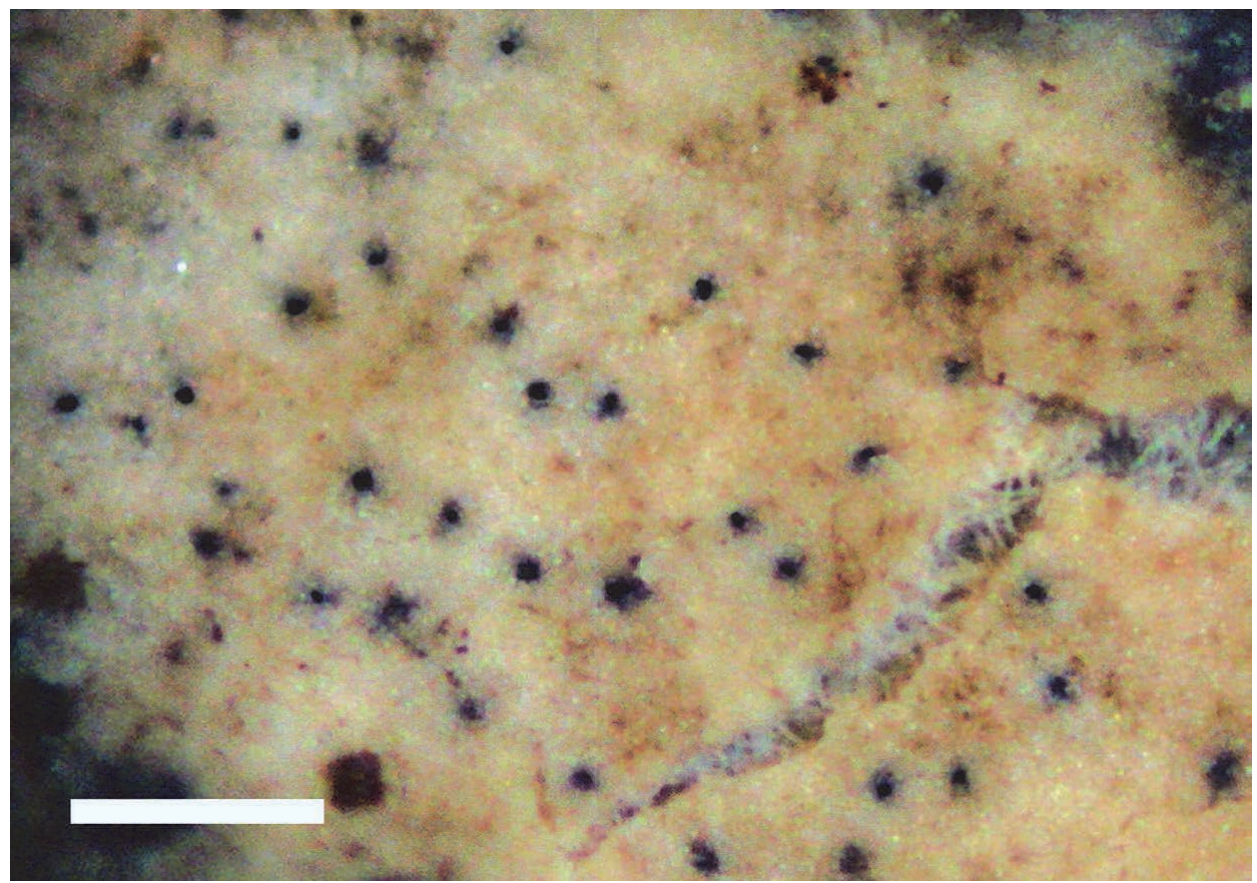

Fig. 4. Sphaerellothecium parmotremae (holotype): habitus with immersed perithecia. Scale $=0.2 \mathrm{~mm}$ 
Ascomata perithecioid, globose, blackish, immersed to semi-immersed, 30-50 $\mu \mathrm{m}$ in diam.; perithecial wall 8-15 $\mu \mathrm{m}$ thick, in the upper part dark brown, $\mathrm{K}-$, in the lower part pale to medium brown; cells in surface view of angular to somewhat elongate shape, $3-5 \times 3-8 \mu \mathrm{m}$ wide, wall irregularly thickened; periphyses not observed; centrum of ascomata K/I-, without any visible paraphysoids or pseudoparaphyses; asci broadly ellipsoid to obpyriform, wall apically thickened, with a distinct ocular chamber, K/I- (epiplasma K/I-), 22-27 × 10-12 $\mu \mathrm{m}, 8$-spored; ascospores hyaline, ellipsoid to ovoid, 1-septate, smooth walled, without a visible perispore, mostly with 2 guttules per cell (material observed in water), 8-10 × 2.5-3 $\mu \mathrm{m}$, upper cell slightly broader and sometimes shorter. Pycnidia not observed.

Etymology: The epithet refers to the host genus.

Distribution and ecology: The species is known from the type locality on São Miguel in a coastal area, on $\mathrm{N}$ exposed steep volcanic outcrops, growing on Parmotrema perlatum (Huds.) Choisy.

Taxonomic notes: The perithecia and ascospores measurements are different from the description of Sphaerellothecium parmeliae Diederich et Etayo in Etayo and Diederich (1998), which is described from Parmelia s. str. The perithecia in this latter are $25-40(-60) \mu \mathrm{m}$, semi-immersed to superficial, arising from large black necrotic areas (Etayo and Diederich 1998), which is not the case in the new species (perithecia 30-50 $\mu \mathrm{m}$, immersed to semi-immersed, without black necrotic areas). A similar species, recently described is Sphaerellothecium giraltiae van den Boom has the same kind of slightly immersed vegetative hyphal net, but has much shorter asci $(15-17 \times 10-12 \mu \mathrm{m} ; 22-27 \times 10-12$ $\mu \mathrm{m}$ in the new species) and shorter ascospores ((5.5-)6-8 $\mu \mathrm{m} ; 8-10 \mu \mathrm{m}$ in the new species), it is known from different Rinodina species (van den Boom 2010).

\section{Stigmidium micareae van den Boom, spec. nova}

(Fig. 5)

Mycobank no.: MB 815837

A lichenicolous fungus on thallus of Micarea alabastrites (Nyl.) Coppins; ascomata perithecioid, subglobosis to globosis, semi-immersis, 30-80 $\mu \mathrm{m}$ in diam., peridium paraplectenchymatous, medium brown, hymenium $I-$, interascal filaments, relative short, asci 45-55 × 9-12(-14) $\mu \mathrm{m}, 8$-spored, ascospores hyaline, 15-20 $\times$ 2.5-3.5(-4) $\mu \mathrm{m}, 1(-2)$-septate.

Type: Portugal; The Azores, Terceira, NW of Angra do Heroismo, Reserva Florestal Viveira da Falca, picnic area, with many mature Cryptomeria trees, some Acer trees and Camellia, $460 \mathrm{~m}, 38^{\circ} 42.90^{\prime} \mathrm{N} ; 2^{\circ}$ 16.78’ W, 28.07.2014, P. \& B. van den Boom 51866 (holotype: $\mathrm{B}$; isotype: hb. v. d. Boom). 
Vegetative hyphae poorly developed, pale to medium brown, smooth, pigmentation even, composed of elongate cells $2.5-3.5 \mu \mathrm{m}$ in diam., not constricted at the septa, branched, immersed in the host tissues, I-.

Ascomata perithecioid, black, shiny, subglobose, to globose, sometimes somewhat conical above, with an ostiole, without appendices or projections, 30-80 $\mu \mathrm{m}$ in diam., semi-immersed in the host thallus, numerous, dispersed, occasionally aggregated; peridium paraplectenchymatous, medium brown, evenly coloured, in surface view of textura angularis, up to $10 \mu \mathrm{m}$ thick, composed of unevenly pigmented cells of $2.5-4 \mu \mathrm{m}$ across, $\mathrm{K}-$, I-; hymenial gel I-, K/I-; ostiolar filaments not developed; interascal filaments relative short, branched; asci bitunicate, usually markedly thickened below the middle, often with a distinct long foot, endoascus strongly thickened above, internal apical beak often distinct and long, 45-55 × 9-12(-14) $\mu \mathrm{m}, 8$-spored, I-, K/I-, with paler area just above apical beak; ascospores colourless, surface smooth, without a perispore, narrowly fusiform, occasionally narrowly obovate, with the greatest breadth above the middle, 15-20 × 2.5-3.5(-4) $\mu \mathrm{m}, 1(-2)$-septate, not or slightly constricted at the septum, but sometimes with 1-2 oil guttules per cell, overlapping in 2-3 rows in an ascus. Pycnidia not observed.

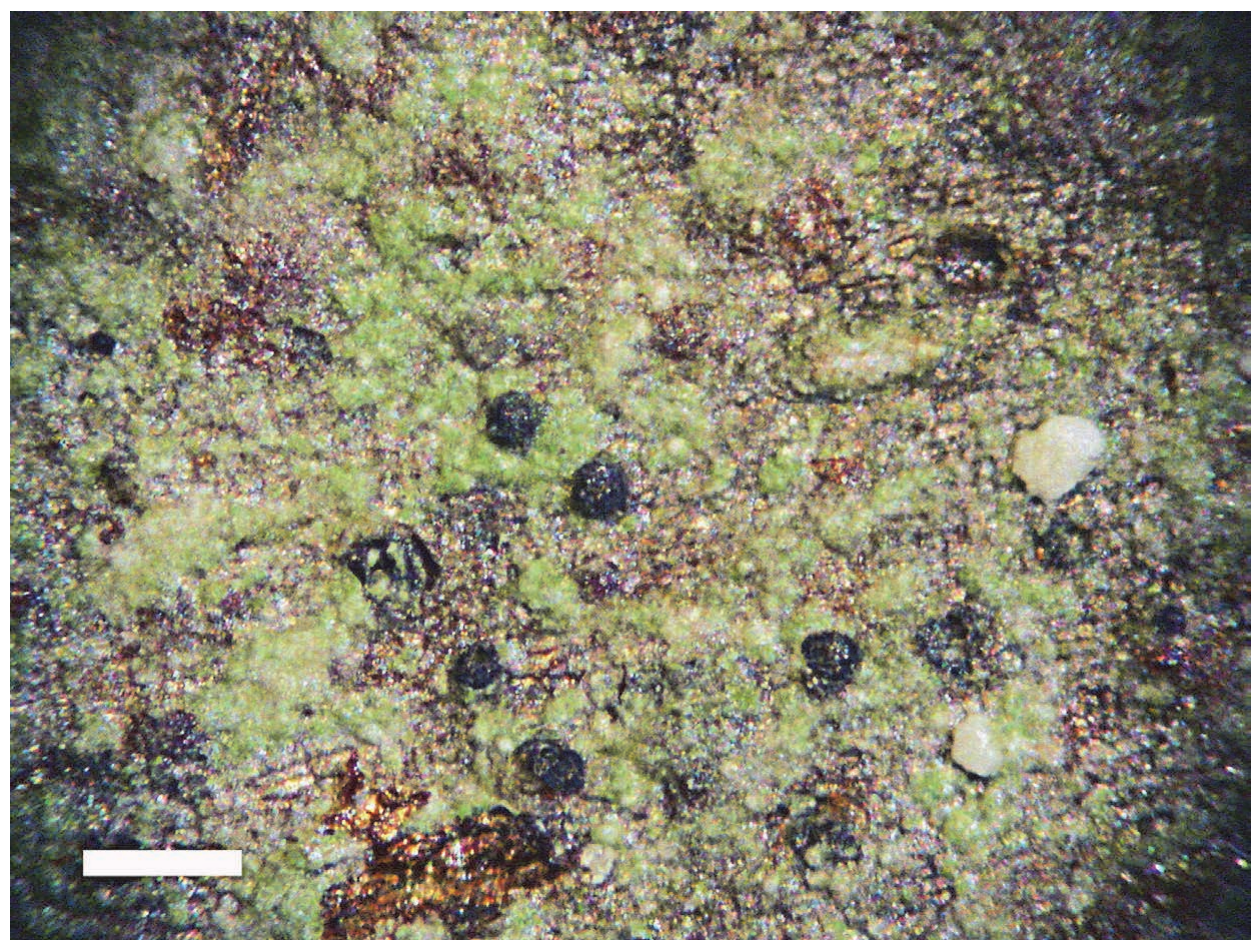

Fig. 5. Stigmidium micareae (holotype): habitus with semi-immersed perithecia. Scale $=0.2 \mathrm{~mm}$ 
Etymology: The epithet refers to the host genus.

Distribution and ecology: The new Stigmidium species is known from the type locality on Terceira in the west of the island $c a 3 \mathrm{~km}$ from the southwest coast, an open place with scattered trees, at $460 \mathrm{~m}$ altitude. It grows on trunks of Cryptomeria trees.

Taxonomic notes: Some Stigmidium species have relatively long ascospores of more than $20 \mu \mathrm{m}$ long, but these are mostly all much wider, up to $c a 10 \mu \mathrm{m}$. However, the similar Stigmidium arthoniae (Arnold) Hafellner has ascospores of 17-22 $\times 4-5 \mu \mathrm{m}$ with 1(-2) septa. These are clearly wider than in the new species, which are 15-20 × 2.5-3.5(-4) $\mu \mathrm{m}$ and it is only known from the host Arthonia radiata (Pers.) Ach. The ascomata are much wider (100-200 $\mu \mathrm{m})$ than in the new species $(30-80 \mu \mathrm{m})$. This latter species is known from the Canary Islands (Hernández-Padrón and Pérez-Vargas 2010). Stigmidium microspilum (Körber) D. Hawksw. has somewhat comparable ascospores (14-19 × $3-5 \mu \mathrm{m}$ vs. $15-20 \times 2.5-3.5(-4) \mu \mathrm{m})$, but the ascomata are $80-120 \mu \mathrm{m}$ in diam., vs. $30-80 \mu \mathrm{m}$. This species is only known from the host Graphis scripta. The following Stigmidium species have narrow ascospores, somewhat comparable

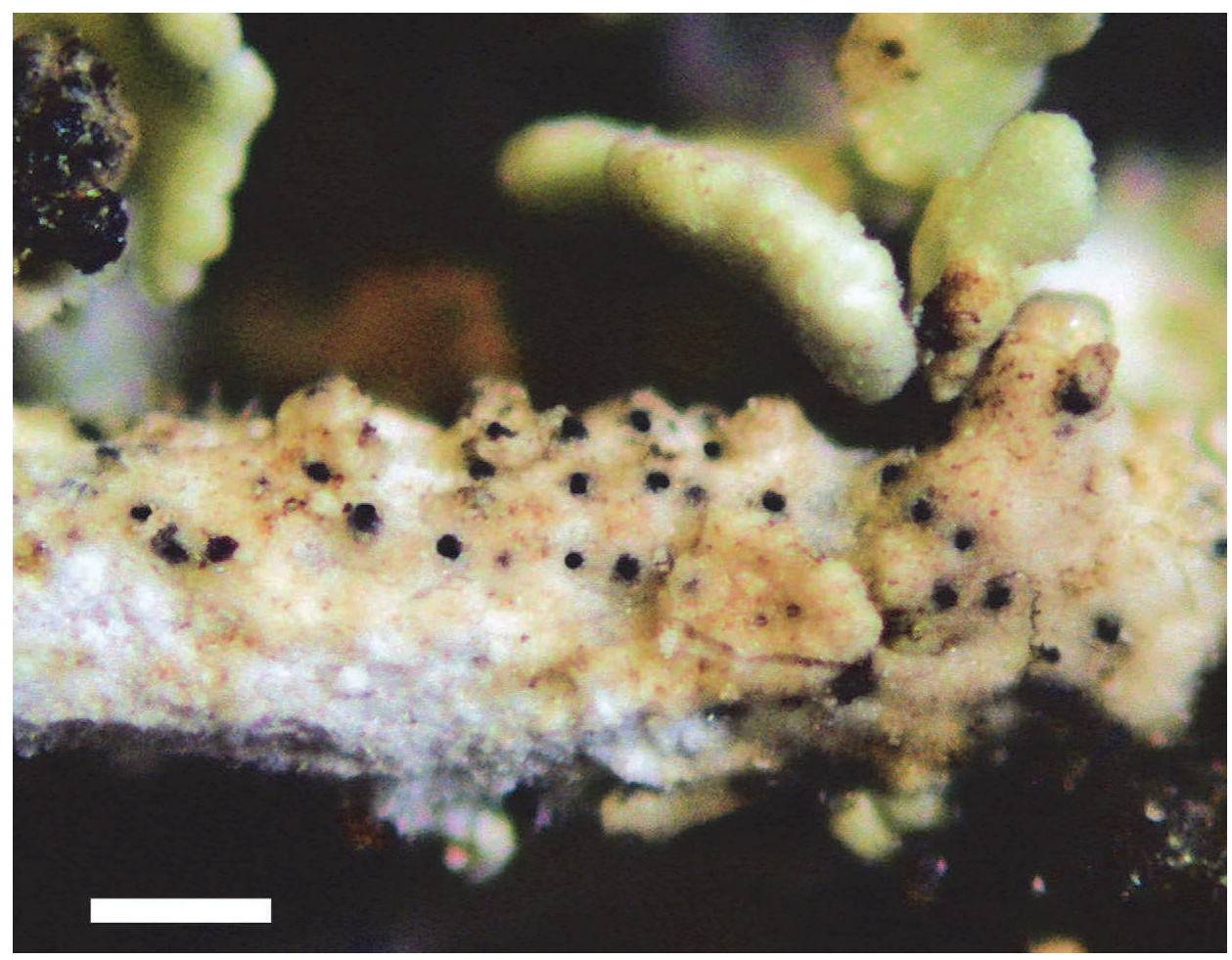

Fig. 6. Stigmidium subcladoniicola (holotype): habitus with immersed perithecia. Scale $=0.2 \mathrm{~mm}$ 
with those of the new species $(15-20 \times 2.5-3.5(-4) \mu \mathrm{m}$, but they all are shorter: S. heterodermiae Etayo $(10.5-13 \times 2.5-3 \mu \mathrm{m})$, S. microcarpum Alstrup et J. C. David $(7-9 \times 2-3 \mu \mathrm{m})$ and S. microsporum Etayo et Osorio $(5.5-6 \times 2-2.5 \mu \mathrm{m})$. However, these latter three have different hosts.

Additional specimens examined: Portugal; The Azores, Terceira, NW of Angra do Heroismo, Reserva Florestal Viveira da Falca, picnic area, with many mature Cryptomeria trees, some Acer trees and Camellia, $38^{\circ} 42.90^{\prime} \mathrm{N} ; 27^{\circ} 16.78^{\prime} \mathrm{W}$, on Cryptomeria, $460 \mathrm{~m}$, 28.06.2014, P. \& B. van den Boom 51356 (hb. v. d. Boom).

Stigmidium subcladoniicola van den Boom, spec. nova (Fig. 6)

Mycobank no.: MB 815838

A Stigmidium species similar to the lichenicolous fungus Stigmidium cladoniicola Zhurb. et Diederich, but differs in the smaller ascomata, immersed to semiimmersed, 30-50 $\mu \mathrm{m}$ diam., much smaller asci of 17-25 × 7-9 $\mu \mathrm{m}$ and much smaller ascospores of (6-)6.5-7 × 2-2.5 $\mu \mathrm{m}$.

Type: Portugal; The Azores, Terceira, NW of Angra do Heroismo, Reserva Florestal Viveira da Falca, picnic area, with many mature Cryptomeria trees, some Acer trees and on Camellia, $38^{\circ} 42.90^{\prime} \mathrm{N} ; 27^{\circ} 16.78^{\prime} \mathrm{W}, 460 \mathrm{~m}$, on Cladonia sp., 28.06.2014, P. \& B. van den Boom 51348 (holotype: B; isotype: hb. v. d. Boom).

Vegetative hyphae rather well developed, pale to medium brown, smooth, pigmentation even, composed of elongate cells $2.5-5 \mu \mathrm{m}$ in diam., not constricted at the septa, sparsely branched, immersed in the host tissues, I-.

Ascomata perithecioid, (brownish) black, shiny, subglobose to globose, sometimes somewhat conical above, with an ostiole, without appendices or projections, 30-50 $\mu \mathrm{m}$ in diam., immersed to semi-immersed in the host thallus, numerous, scattered to sometimes crowded; peridium brown, evenly coloured, in surface view of textura angularis, 4-6 $\mu \mathrm{m}$ thick, composed of dark brown pigmented angular cells of $c a 5 \times 5 \mu \mathrm{m}$ or up to $8 \times 5-6 \mu \mathrm{m}$. K-, I-; hymenium I-, K/I-; ostiolar and interascal filaments not observed; asci bitunicate, broadly cylindrical to saccate, often with a distinct short foot, endoascus strongly thickened above, internal apical beak often distinct, 17-25 × 7-9 $\mu \mathrm{m}, 8$-spored, I-, K/I-; ascospores colourless, old ascospores sometimes pale brown, surface smooth, without a perispore, narrowly ellipsoid, occasionally narrowly obovate, with the greatest breadth above the middle, (6-)6.5-7 $\times$ 2-2.5 $\mu \mathrm{m}, 1$-septate, often slightly constricted at the septum, mostly with 2 oil guttules per cell. Pycnidia not observed. 
Etymology: The epithet refers to the similarity with Stigmidium cladoniicola.

Distribution and ecology: This new species is only known from the type locality in Terceira. It is known from trunks of Cryptomeria japonica, growing mainly on squamules of an unidentified Cladonia. It occurs in inland, hilly areas.

Taxonomic notes: The only known Stigmidium species growing on Cladonia is Stigmidium cladoniicola Zhurb. et Diederich, described from C. macrophylla (Schaer.) Stenh. differs in larger perithecia (up to $80 \mu \mathrm{m}$ in diam.), which are semi-immersed in the host thallus to sessile, much bigger asci of 33-42 $\times$ $13-16 \mu \mathrm{m}$ vs. $17-25 \times 7-9 \mu \mathrm{m}$, much larger ascospores of $11.5-15 \times 3-4 \mu \mathrm{m}$ vs. $(6-) 6.5-7 \times 2-2.5 \mu \mathrm{m}$. S. microcarpum Alstrup et J. C. David has somewhat the same ascomata (35-50 $\mu \mathrm{m}$ in diam.) and slightly bigger ascospores $(7-9 \times 2-3$ $\mu \mathrm{m})$, it has an apical pore of $4-7 \mu \mathrm{m}$, which is not visible in the new species, it has a different host, Flavocetraria cucullata (Bellardi) Kärnefelt et Thell and is known from Greenland.

Thelocarpon microsporum van den Boom, spec. nova (Fig. 7)

Mycobank no.: MB 815839

Thallus absent, growing corticolous; ascomata perithecioid, globose, slightly flattened at the upper part, sessile, 0.05-0.15(-0.2) $\mathrm{mm}$ in diam., yellow-pruinose, hymenium 45-50 $\mu \mathrm{m}$ high KI+ faint bluish, hymenial gel absent, paraphyses thin, branched; ascospores 1.5-2(-2.5) $\mu \mathrm{m}$ in diam.

Type: Portugal; The Azores, Terceira, NW of Angra do Heroismo, NNE of Santa Bárbara, Serra de Santa Bárbara, road to the summit, forests with mainly Cryptomeria trees, trees at edge of forest, $38^{\circ} 43.49^{\prime} \mathrm{N} ; 2^{\circ} 19.33^{\prime} \mathrm{W}, 800 \mathrm{~m}, 01.07 .2014, \mathrm{P}$. \& B. van den Boom 51623 (holotype: B; isotype: hb. v. d. Boom). nearby.

Thallus absent, but possibly associated with Micarea sp., growing close

Ascomata perithecioid, globose, to somewhat flattened at the upper part, sessile, constricted at the base, emarginated, $0.05-0.15(-0.2) \mathrm{mm}$ in diam., yellow-pruinose, hymenium $45-50 \mu \mathrm{m}$ high, $\mathrm{K} / \mathrm{I}+$ faint bluish, hymenial gel absent; paraphyses branched, apices not widened, $0.8-1.2 \mu \mathrm{m}$ wide, but forming an epithecium incrusted with fine crystals; asci broadly ellipsoid, wall K/ I+ blue, thickened at apex into a tholus; tholus K/I+ blue, multispored, with $>50$ spores; ascospores globose, very small, $1.5-2(-2.5) \mu \mathrm{m}$ in diam., without oil droplets. Pycnidia not observed.

Etymology: The epithet refers to the very small ascospores. 
Distribution and ecology: The species is known from the type locality on Terceira (Azores), and known from two inland localities from 500-800 m altitude, growing on trunks of Cryptomeria trees and Erica shrubs.

Taxonomic notes: This new Thelocarpon species is easily recognised by very small globose ascospores of $1.5-2(-2.5) \mu \mathrm{m}$. Two other Thelocarpon species with paraphyses and globose ascospores are T. sphaerosporum H. Magn. and T. depressulum Vain. The former has much larger ascospores, of 4.5-5.5 $\mu \mathrm{m}$ vs. $1.5-2(-2.5) \mu \mathrm{m}$, it has more or less apothecioid ascomata of $0.15-0.2 \mathrm{~mm}$ vs. perithecioid ascomata of $0.05-0.15(-0.2) \mathrm{mm}$ and hymenial gel is present vs. hymenial gel is absent and is an alpine species, the latter has apothecioid ascomata, which are marginate and has an exposed disc vs. perithecioid ascomata, globose ascospores of $2-3 \mu \mathrm{m}$ vs. $1.5-2(-2.5) \mu \mathrm{m}$, it grows saxicolous or lignicolous and is known from Sweden, Norway (Santesson et al. 2004) and the Tatra Mountains (Poelt and Vězda 1977).

Additional specimens examined: Portugal; The Azores, Terceira, NE of Serreta, north trail to Lagoínha, Cryptomeria japonica trees (in forest), Myrica faya trees and Erica, $38^{\circ} 45.28^{\prime}$ $\mathrm{N} ; 27^{\circ} 20.50^{\prime} \mathrm{W}$, on Cryptomeria, 500 m, 02.07.2014, P. \& B. van den Boom 51705 (hb. v. d. Boom); ibid. on Erica. P. \& B. van den Boom 51689 (hb. v. d. Boom).

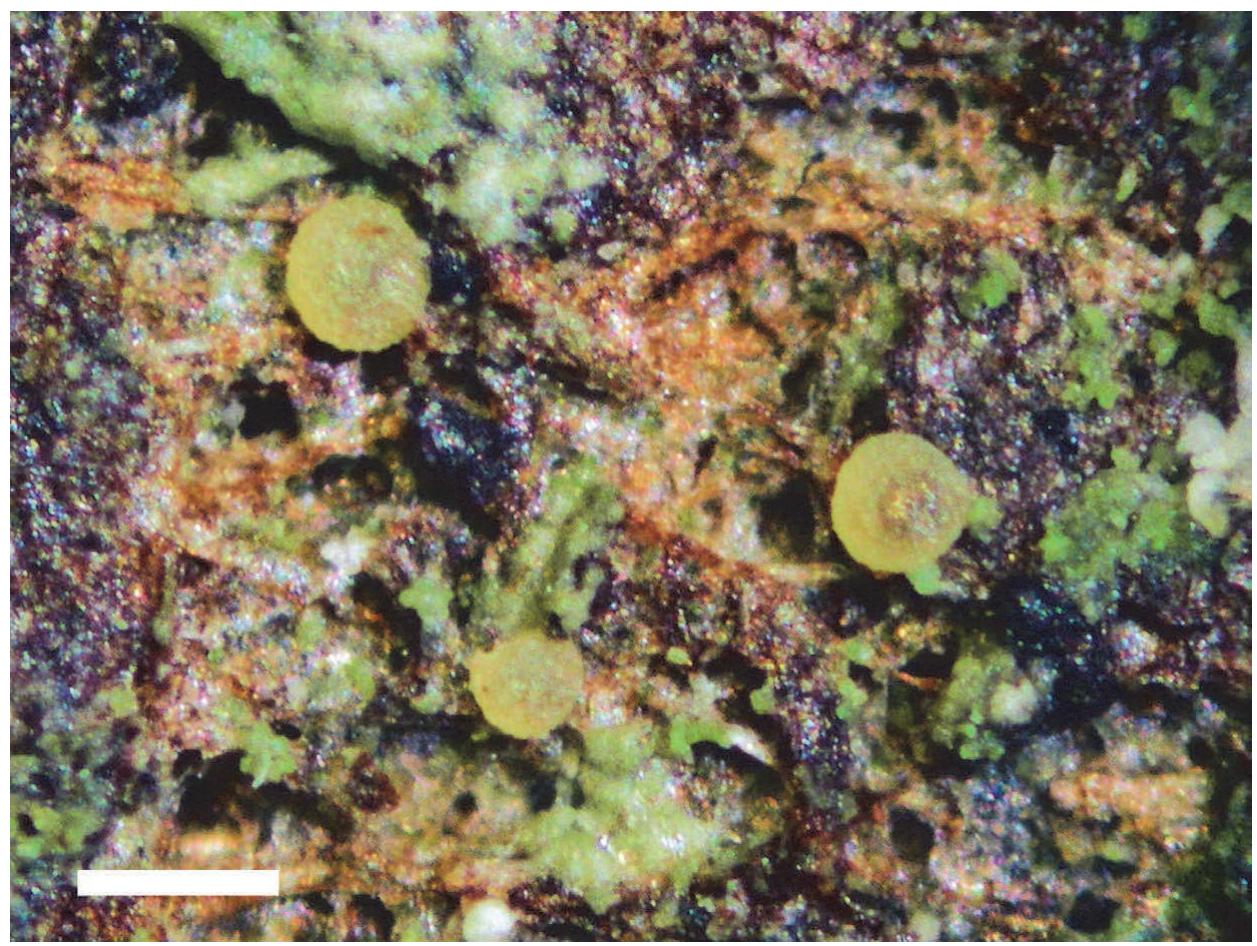

Fig. 7. Thelocarpon microsporum (holotype): habitus with immersed perithecia. Scale $=0.2 \mathrm{~mm}$ 
New records for the Azores, São Miguel and Terceira

Abrothallus hypotrachynae Etayo et Diederich - Loc. 5 on unidentified tree, on Hypotrachyna, B46582; Loc. 8 on Erica on Hypotrachyna, B46638; Loc. 28 on Erica on Hypotrachyna, B51564, B51565; Loc. 35 on Cryptomeria on Parmelinopsis, B51657. - Mentioned in Gabriel (2008) but no information about the distribution.

Abrothallus parmotrematis Diederich - Loc. 47 on Cryptomeria, on Parmotrema perlatum, B51861. - Mentioned from Pico and São Jorge by Diederich (2011) and from São Jorge by Berger and Priemetzhofer (2008).

Abrothallus welwitschii Mont. - Loc. 18 on Acer on Sticta, B51372. - Gabriel (2008) gives no information about the distribution.

Ampullifera foliicola Deighton - Loc. 18 on leaf of Camellia, on Byssoloma subdiscordans (Nyl.) P. James, B51343. - New to the Azores.

Anisomeridium robustum Orange, Coppins et Aptroot - Loc. 11 on Populus, B46744. - This species was previously not known fertile, but here we have found perithecia up to $0.4 \mathrm{~mm}$ wide with 1-septate ascospores, septum towards the lower end of the ascospore, 10-12 × 5.5-7 $\mu \mathrm{m}$. It was recently described in Coppins and Aptroot (2008). New to the Azores.

Arthonia cinnabarina (DC.) Wallr. - Loc. 6 on Laurus, B46606. - Gabriel (2008) gives no information about the distribution.

Arthonia digitatae Hafellner - Loc. 21 on Cryptomeria, on Cladonia, B51453. - New to the Azores.

Arthonia microsticta Vain. - Loc. 22 on Pittosporum, on Parmotrema reticulatum, B51478. - New to the Azores.

Bacidia sipmanii M. Brand, Coppins, van den Boom et Sérus. - Loc. 24 on acidic rock, B51784. - New to the Azores.

Biatoropsis usnearum Räsänen - Loc. 18 on Cryptomeria, on Usnea, B51334. - So far only known from São Miguel (Gabriel 2008).

Byssoloma croceum Sérus. et Puntillo - Loc. 28 on Erica, B51556. - This species is known from the Canary Islands, Madeira and Italy (Carvalho et al. 2008, Sérusiaux 1998). New to the Azores.

Byssoloma kakouettae (Sérus.) Lücking et Sérus. - Loc. 21 on leaf of Camellia, B51454, B51463, B51456; Loc. 24 on Eucalyptus, B51498; Loc. 40 on Azalea, B51748. - New to the Azores.

Byssoloma marginatum (Arnold) Sérus. - Loc. 38 on Erica, B51697; Loc. 40 on Eucalyptus, B51736; Loc. 48 on Erica, B51842, B51849, B51851. - So far only known from São Miguel (Gabriel 2008).

Caloplaca chrysophthalma Degel. - Loc. 41 on Erica, B51780. - Only known from Faial (Gabriel 2008). 
Caloplaca pyracea (Ach). Th. Fr. - Loc. 42 on Erica, B51802. - New to the Azores.

Chaenotheca brunneola (Ach.) Müll. Arg. - Loc. 21 on Cryptomeria, B51452. - It was known from São Miguel (Berger and Priemetzhofer 2008).

Cladonia homosekikaica Nuno - Loc. 12 terricolous, B46755. - New to the Azores. Det. T. Ahti.

Cladonia mediterranea P. A. Duvign. et Abbayes - Loc. 33 terricolous, B51610. - New to the Azores.

Cladonia ramulosa (With.) J. R. Laundon - Loc. 12 terricolous, B46750, B46760. - In Gabriel (2008) only recorded from Terceira.

Coccocarpia palmicola (Spreng.) Arv. et D. J. Galloway - Loc. 21 on Juniperus, B51419. - Known from Faial, Floris and Pico (Gabriel 2008).

Coenogonium frederici (Kalb et Vězda) Kalb et Lücking - Loc. 43 on Myrica, B51807. - Already known from São Miguel (Gabriel 2008).

Coenogonium luteum (Dicks.) Kalb et Lücking - Loc. 35 on Cryptomeria, B51646. - Known from Pico and São Miguel (Gabriel 2008).

Degelia ligulata P. M. Jørg. et P. James - Loc. 41 on volcanic rock, B51781. - Only known from Faial and Santa Maria (Gabriel 2008).

Diploicia subcanescens (Werner) Hafellner et Poelt - Loc. 41 on acidic rock, B51783. - Only known from Faial (Gabriel 2008).

Diplolaeviopsis ranula Giralt et D. Hawksw. - Loc. 37 on wood of fence post, on Lecanora strobilina, B51675. - New to the Azores.

Diploschistes actinostomus (Ach.) Zahlbr. - Loc. 13 on volcanic rock, B46763. - Known from Terceira (Gabriel 2008).

Endococcus propinquus (Körb.) D. Hawksw. - Loc. 29 on volcanic rock, on Lecidella sp., B51576. - New to the Azores.

Enterographa crassa (DC.) Fée - Loc. 2 on Ocotea, B46518; Loc. 40 on Azalea, B51745. - Gabriel (2008) gives no information about the distribution.

Enterographa hutchinsiae (Leight.) A. Massal. - Loc. 22 on Pittosporum, B51476. - Known from São Miguel (Gabriel 2008).

Ephebe lanata (L.) Vain. - Loc. 33 on volcanic rock, B51606. This collection is richly fertile. - Known from Faial and Pico (Gabriel 2008).

Fellhanera parvula (Vězda) Vězda - Loc. 18 on leaf of Camellia B51342; Loc. 18 on trunk of Cryptomeria, B51865. - A species known from the Neotropics and tropical Africa (Lücking 2008). The latter specimen has only pycnidia, but the small typical conidia are according to the description and comparable with those on the foliicolous collection. New to the Azores.

Fellhanera seroexspectata Sérus. - Loc. 21 on leaf of Camellia, PB51459. New to the Azores.

Fissurina insidiosa C. Knight et Mitt. - Loc. 18 on branch of Camellia, B51344; Loc. 18 on Acer, B51377. - Known already from three islands, Faial, Pico and São Miguel (Gabriel 2008). 
Fulvophyton sorediatum (Sparrius, P. James et M. A. Allen) van den Boom - Loc. 10 on acidic rock, B46725; Loc. 13 on volcanic rock, B46765, B46822; Loc. 32 on volcanic rock, B51600. - Previously known from São Miguel as Peterjamesia sorediata (Sparrius, P. James et M. A. Allen) D. Hawksw. (Gabriel 2008). Apothecia are very rare (van den Boom and Giralt 2012), but specimen B46822 has a few apothecia.

Glyphis cicatricosa Ach. - Loc. 40 on unidentified tree, B51742. - Only known from São Miguel and Faial (Gabriel 2008).

Graphis longula Kremp. - Loc. 12 on Acer, B46752. Lirellae have a basal to lateral thalline margin. Ascospores are 11-12-septate, 40-60 x 10-12 $\mu \mathrm{m}$, pale brownish when old. - No chemical compounds detected. Graphis elegans is rather similar but differs in the chemistry, it contains norstictic acid. According to Lücking (2009), this is a pantropical species.

Heterodermia albicans (Pers.) Swinscow et Krog - Loc. 38 on Ilex, B51726. Previously known from Faial and São Miguel (Gabriel 2008).

Jamesiella anastomosans (P. James et Vězda) Lücking, Sérus. et Vězda Loc. 8 on Erica (fertile), B46636; Loc. 19 on wood fence post, B51406; Loc. 38 on Erica, B51694; Loc. 46 on Erica, B51836, B51852. - New to the Azores.

Lecania fructigena Zahlbr. - Loc. 13 on concrete, B46793. - New to the Azores.

Lecania naegelii (Hepp) Diederich et van den Boom - Loc. 9 on wood of fence post, B46682. - Previously only known from Terceira (Gabriel 2008).

Lecania rabenhorstii (Hepp) Arnold - Loc. 20 on calcareous rock, B51392. - New to the Azores.

Lecanographa dialeuca (Cromb.) Egea et Torrente - Loc. 9 on acidic rock, B46694. - New to the Azores. Det. D. Ertz.

Lecanora strobilina (Spreng.) Kieff. - Loc. 10 on Populus, B46742; Loc. 11 on Populus, B46742; Loc. 25 on Erica, B51800; Loc. 28 on Erica, B51559; Loc. 30 on Cryptomeria, B51859. - Gabriel (2008) gives no information about the distribution.

Lecidea exigua Chaub. - Loc. 3 on Quercus, B46540. - New to the Azores.

Leptogium cochleatum (Dicks) P. M. Jørg. et P. James - Loc. 37 on Myrica, B51669. - Known from Pico and São Miguel (Gabriel 2008).

Lichenoconium erodens M. S. Christ. et D. Hawksw. - Loc. 4 on Cryptomeria, on Parmotrema sp., B46573; Loc. 12 on Acer, on Graphis longula. - New to the Azores.

Lichenodiplis lecanorae (Vouaux) Dyko et D. Hawksw. - Loc. 42 on Erica, on Lecanora sp., B51799. Known from São Jorge (Gabriel 2008).

Llimonaea occulta Egea et Torrente - Loc. 32 on volcanic rock, B51596, B51599; Loc. 41 on volcanic rock, B51758. - New to the Azores. 
Lobaria immixta Vain. - Loc. 21 on Azalea, B51457. - It was only known from São Miguel (Gabriel 2008).

Marchandiobasidium aurantiacum Diederich et Schultheis - Loc. 4 on unidentified tree, on Teloschistes chrysophthalma, B46563. - New to the Azores.

Micarea coppinsii Tønsberg - Loc. 16 terricolous, B46806, B46807, B46809. - The collections are richly fertile. New to the Azores.

Micarea micrococca (Körb.) Gams ex Coppins - Loc. 35 on Cryptomeria, B51636; Loc. 38 on Erica, B51713. - New to the Azores.

Micarea viridileprosa Coppins et van den Boom - Loc. 42 on Erica, B51791. - New to the Azores.

Milospium graphideorum (Nyl.) D. Hawksw. - Loc. 25 on Laurus nobilis, B51508. - New to the Azores.

Minutoexcipula mariana V. Atienza - Loc. 25 on Laurus nobilis, B51509; Loc. 25 Quercus robur, B51513; both on Pertusaria. - Known from Flores (Berger and Priemetzhofer 2008) and São Miguel (Diederich 2003).

Muellerella hospitans Stitzenb. - Loc. 43 on Myrica, on thallus of Bacidia, B51869. - It is rather unusual to find the perithecia on the thallus of a Bacidia. This species is known growing on apothecia of a Bacidia. However, the characters fit well with $M$. hospitans, the brown ascospores are $2.5-3 \times 2-2.5 \mu \mathrm{m},>100$ spores per ascus, the perithecia are somewhat smaller than $100 \mu \mathrm{m}$ diam. New to the Azores.

Muellerella pygmaea (Körb.) D. Hawksw. - Loc. 26 on stone of wall, on unidentified crust. Berger and Priemetzhofer (2008) record this species from São Miguel.

Mycoblastus alpinus (Fr.) Hellb. - Loc. 39 on Ilex, B51718. - According to Smith et al. (2009), this species is very rarely fertile in Great Britain. This specimen is fertile. New to the Azores.

Myriotrema sordidescens (Fée) Kalb - Loc. 21 on Cryptomeria, B51442; Loc. 38 on Erica, B51690; Loc. 46 on Erica, B51835. - New to the Azores.

Opegrapha cesareensis Nyl. - Loc. 32 on overhanging volcanic outcrop, B51602. - New to the Azores.

Opegrapha vulgata (Ach.) Ach. - Loc. 41 on Erica, B51788. - Only mentioned from São Jorge (Gabriel 2008).

Peltigera hymenina (Ach.) Delise - Loc. 19 terricolous, B51394; Loc. 33 terricolous, B51605, B51609, B51919; Loc. 34 on dead standing tree, B51625. Only known from São Jorge and São Miguel (Gabriel 2008).

Pertusaria pseudocorallina (Lilj.) Arnold - Loc. 33 on volcanic rock, B51615. - According to Gabriel (2008) it is only known from Faial.

Phaeophyscia orbicularis (Neck.) Moberg - Loc. 30 on Morus, B51585. Only known from São Jorge (Gabriel 2008). 
Physcia tribacioides Nyl. - Loc. 22 on Pittosporum, B51484. - Known from Faial, São Jorge and São Miguel (Gabriel 2008).

Polycoccum montis-wilhelmii Diederich - Loc. 47 on Cryptomeria, B51862, on Parmotrema perlatum. - This species is described from Papua New Guinea (Aptroot et al. 1997), from Hypotrachyna as the first species of the genus on Parmelia s. 1. Etayo and Sancho (2008) recorded this species on Parmelia saxatilis from Chile. Our record fits well with the original description except that the perithecia in our specimen are somewhat smaller (ca $50 \mu \mathrm{m}$ vs $100 \mu \mathrm{m})$. New to the Azores.

Porina aenea (Wallr.) Zahlbr. - Loc. 26 on Myrica, B51808; Loc. 35 on Cryptomeria, B51665. - Only known from São Miguel (Gabriel 2008).

Porina curnowii A. L. Sm. - Loc. 13 on volcanic rock, B46768. - Only known from Flores and São Jorge (Gabriel 2008).

Porina leptalea (Durieu et Mont.) A. L. Sm. - Loc. 35 on Cryptomeria, B51650; Loc. 38 on Erica, B51677. - New to the Azores.

Porina leptospora (Nyl.) A. L. Sm. - Loc. 22 on Pittosporum, B51480; Loc. 24 on Eucalyptus, B51499; Loc. 28 on Erica, B51570; Loc. 42 on Erica, B51874. Only known from São Miguel (Gabriel 2008). Schumm and Aptroot (2013) recorded this species from Terceira as P. cf. leptospora, with 11-13-septate, 35-37 $\times 4-5 \mu \mathrm{m}$ ascospores. We have ascospores of 30-45 $\times(2-) 2.5-3 \mu \mathrm{m}, 6-9$-septate.

Porina tetramera (Malme) R. Sant. - Loc. 18, B51340; Loc. 21, B51455. Both on leaf of Camellia. New to the Azores.

Porpidia crustulata (Ach.) Hertel et Knoph - Loc. 45 on wood of fence post, B51823. - Known from Pico and São Miguel (Gabriel 2008).

Porpidia platycarpoides (Bagl.) Hertel - Loc. 26 on acidic stone of wall, B51526. - Known from Pico and São Miguel (Gabriel 2008).

Porpidia soredizodes (Lamy.) J. R. Laundon - Loc. 33 on volcanic rock, B51611. - Known from São Miguel (Gabriel 2008).

Pyrenidium actinellum Nyl. - Loc. 33 volcanic rock, on Baeomyces rufus, B51618. - Known from São Miguel (Gabriel 2008).

Pyrenula dermatodes (Borrer) Schaer. - Loc. 3 on Laurus, B46533. - Known from Faial, Flores, Pico and Terceira (Gabriel 2008).

Pyrenula hibernica (Nyl.) Aptroot - Loc. 39 on Ilex, B51724. - Gabriel (2008) gives no information about the distribution.

Pyrenula laevigata (Pers.) Arnold - Loc. 19 on Erica, B51414; Loc. 35 on Cryptomeria, B51642; Loc. 39 on Ilex, B51729. - Recorded from São Miguel and São Jorge by Berger and Priemetzhofer (2008).

Pyrrhospora quernea (Dicks.) Körb. - Loc. 28 on Myrica, B51555. - Only known from São Jorge and São Miguel (Gabriel 2008).

Rhizocarpon infernulum (Nyl.) Lynge - Loc. 33 on acidic rock, B51612, B51607. - Recorded from São Miguel by Berger and Priemetzhofer (2008). 
Roccellographa circumscriptum (Taylor) Ertz et Tehler - Loc. 10 on acidic rock, B46724; Loc. 13 on volcanic rock, B46770; Loc. 24 on volcanic rock, B51759; Loc. 32 on volcanic rock, B51598. - New to the Azores.

Skyttea nitschkei (Körb.) Sherwood, D. Hawksw. et Coppins - Loc. 20 on Erica, on Thelotrema lepadinum, B51413. - Recorded from São Miguel by Schumm and Aptroot (2013).

Sphinctrina tubaeformis A. Massal. - Loc. 22 on Pittosporum, on Pertusaria B51482. - Only known from São Miguel (Gabriel 2008).

Stereocaulon macaronesicum Purvis et P. James - Loc. 15 terricolous, B46802. - Known from Faial, Flores, Pico, São Jorge and Terceira (Gabriel 2008).

Sticta sylvatica (Huds.) Ach. - Loc. 21 on Juniperus, B51417, B51429. - No information about distribution in Gabriel (2008).

Syncesia myrticola (Fée) Tehler - Loc. 27 on Mimosaceae, B51543. - No information about distribution in Gabriel (2008), but recorded from São Miguel and Flores by Berger and Priemetzhofer (2008).

Syzygospora bachmannii Diederich et M. S. Christ. - Loc. 18 on Cryptomeria, B51347; Loc. 20 on Juniperus, B51418; Loc. 35 on Cryptomeria, B51661; all on Cladonia squamules. - Only known from São Miguel (Gabriel 2008).

Teloschistes chrysophtalmus (L.) Beltr. - Loc. 22 on Pittosporum, B51483. Only known from São Miguel (Gabriel 2008).

Teloschistes flavicans (Sw.) Norman - Loc. 28 on Myrica, B51546. - Only known from Faial and Flores (Gabriel 2008).

Thelopsis rubella Nyl. - Loc. 2 on Quercus ilex, B46517. - Only known from Faial (Gabriel 2008).

Thelotrema laurisilvae R. Lücking et O. Breuss - Loc. 40 on Mimosaceae, B51738. - Recently described from Madeira (Lücking and Breuss 2012). New to the Azores.

Toninia aromatica (Turner) A. Massal. - Loc. 9 on calcareous rock, B46681, B46710; Loc. 13 terricolous, B46791. - No information about distribution in Gabriel (2008).

Toninia mesoidea (Nyl.) Zahlbr. - Loc. 9 on volcanic rock, B46686, B46700. - Only known from São Jorge (Gabriel 2008).

Toninia thiopsora (Nyl.) H. Olivier - Loc. 33 on volcanic rock, B51616. Only known from Pico (Gabriel 2008). Det. E. Timdal.

Trapelia glebulosa (Sm.) J. R. Laundon - Loc. 33 on volcanic rock, B51608. - Only known from Faial (Gabriel 2008).

Trapeliopsis gymnidiata Aptroot et Schumm - Loc. 9, B46707; Loc. 13, B46790; both terricolous. - New to the Azores.

Tremella lobariacearum Diederich et M. S. Christ. - Loc. 8 on unidentified tree, B46666; Loc. 37 on Myrica, B51673; both on Lobaria sp. - Only known from São Jorge (Gabriel 2008). 
Tremella ramalinae Diederich - Loc. 10 on unidentified shrub, on Ramalina, B46735. - New to the Azores.

Vouauxiella verrucosa (Vouaux) Petr. et Syd. - Loc. 22 on Pittosporum, on Lecanora sp., B51477. - Known from São Miguel and São Jorge (Berger and Priemetzhofer 2008).

Waynea stoechadiana (Abassi Maaf et Cl. Roux) Cl. Roux et P. Clerc - Loc. 26 on Tamarix, B51537. - New to the Azores.

Acknowledgements - I would like to thank the anonymous referees for useful comments and Harrie Sipman for his constructive comments after the review. Ted Ahti and Raquel Pino are thanked for the identification of some Cladonia specimens, Damien Ertz for a specimen of Lecanographa, Einar Timdal for a specimen of Toninia. Special thanks are due to Bern van den Boom for contributing important specimens during the fieldwork.

\section{REFERENCES}

Aptroot, A., Diederich, P., Sérusiaux, E. and Sipman, H. J. M. (1997): Lichens and lichenicolous fungi from New Guinea. - Biblioth. Lichenol. 64: 1-220.

Berger, F. and Priemetzhofer, F. (2008): Neufunde und interessante Nachweise von Flechten und flechtenbewohnenden Pilzen von den Azoren. - Herzogia 21: 125-146.

Carvalho, P., Figueira, R. and Jones, M. P. (2008): Os líquenes e fungos liquenícolas (Fungi) dos arquipélagos da Madeira e das Selvagens. (The lichens and lichenicolous fungi (Fungi) of the Madeira and Selvagens archipelagos). - In: Borges, P. A. V., Abreu, C., Aguiar, A. M. F., Carvalho, P., Jardim, R., Melo, I., Oliveira, P., Sérgio, C., Serrano, A. R. M. and Vieira, P. (eds): Listagem dos Fungos, Flora e Fauna Terrestres dos Arquipélagos da Maderia e Selvagens. (A list of the terrestrial fungi, flora and fauna of Madeira and Selvagens Archipelagos). Direcção Regional do Ambiente da Madeira and Universidade dos Açores, Funchal and Angra do Heroísmo, pp. 95-122.

Coppins, B. J. and Aptroot, A. (2008): New species and combinations in the lichens of the British Isles. - Lichenologist 40(5): 363-374. http://dx.doi.org/10.1017/s0024282908008165

Diederich, P. (2003): New species and new records of American lichenicolous fungi. - Herzogia 16: 41-90.

Diederich, P. (2007): Sphaerellothecium gallowayi sp. nov., a new lichenicolous ascomycete on Heterodermia from Australia and Papua New Guinea. - Biblioth. Lichenol. 95: 165-169.

Diederich, P. (2011): Description of Abrothallus parmotrematis sp. nov. (lichenicolous Ascomycota). - Bull. Soc. Natur. Luxembourg. 112: 25-34.

Etayo, J. and Diederich, P. (1998): Lichenicolous fungi from the western Pyrenees, France and Spain. IV. Ascomycetes. - Lichenologist 30(2): 103-120. http://dx.doi.org/10.1017/ s0024282992000112

Etayo, J. and Sancho, L. G. (2008): Hongos liquenícolas del Sur de Sudamérica, especialmente de Isla Navarino (Chile). - Biblioth. Lichenol. 98: 1-302. 
Gabriel, R. (2008): Base de dados da biodiversidade dos Açores. Líquenes. - Universidade dos Açores. http://www.azoresbioportal.angra.uac.pt/pesquisa.php? lang=pt\&sstr=1 (visited 10.06.2015).

Hernández-Padrón, C. E. and Pérez-Vargas, I. (2010): División Lichenes y Lichenicolous Fungi. - In: Arechavaleta, M., Rodríguez, S., Zurita, N. and García, A. (eds): Lista de especies silvestres de Canarias (hongos, plantas y animales terrestres). Consejería de Medio Ambliente y Ordenación Territorial Gobierno de Canarias.

Lücking, R. (2008): Foliicolous lichenized fungi. - Flora Neotropica Monograph 103. Organization for Flora Neotropica and The New York Botanical Garden Press, Bronx, New York, 866 pp.

Lücking, R. (2009): The taxonomy of the genus Graphis sensu Staiger (Ascomycota: Ostropales: Graphidaceae). - Lichenologist 41(4): 319-362. http://dx.doi.org/10.1017/ s0024282909008524

Lücking, R. and Breuss, O. (2012): A new species of Thelotrema, a new combination, Leucodecton isidioides, and a key to thelotremoid lichens of Macaronesia (lichenised Ascomycota: Graphidaceae). - Österr. Zeitschr. Pilzk. 21: 127-133.

Poelt, J. and Vězda, A. (1977): Bestimmungsschlüssel europäischer Flechten. Ergänzungsheft I. - Biblioth. Lichenol. 9: 1-258.

Santesson, R., Moberg, R., Nordin, A., Tønsberg, T. and Vitikainen, O. (2004): Lichen-forming and lichenicolous fungi of Fennoscandia. - Museum of Evolution, Uppsala University, Uppsala, Sweden. 359 pp.

Sérusiaux, E. (1998): Deux nouvelles espèces de Byssoloma Trev. (Lichenes, Pilocarpaceae) d'Europe occidentale et de Macaronésie. (Two new species of Byssoloma Trev. (Lichenes, Pilocarpaceae) from western Europe and Macaronesia). - Cryptogamie, Bryol. Lichénol. 19(2-3): 197-209.

Schumm, F. and Aptroot, A. (2013): Flechten Madeiras, der Kanaren und Azoren. Band 2 (Ergänzungsband). - Private edition, $457 \mathrm{pp}$.

Smith, C. W., Aptroot, A., Coppins, B. J., Fletcher, A., Gilbert, O. L., James, P. W. and Wolseley, P. A. (eds) (2009): The lichens of Great Britain and Ireland. - British Lichen Society, London, $1046 \mathrm{pp}$.

van den Boom, P. P. G. (2010): New or interesting lichens and lichenicolous fungi of Gran Canaria (Canary Islands, Spain). - Willdenowia 40: 359-367. http://dx.doi.org/10.3372/ wi.40.40215

van den Boom, P. P. G. and Giralt, M. (2012): Checklist and three new species of lichens and lichenicolous fungi of the Algarve (Portugal). - Sydowia 64(2): 149-207. 